Hyun, B.H., VARGa, C.F. \& RUBin, R.J. (1972) Spontaneous and pathological rupture of the spleen. Archives of Surgery. Chicago, 104, 652.

MilleR, J. (1961) A case of spontaneous rupture of the spleen. British Medical Journal, 2, 490.

ORLOFf, M.J. \& PeSkin, G.W. (1958) Spontaneous rupture of the spleen a surgical enigma. International Abstracts of Surgery, 1, 1.

Phillips, G.M (1972) False positive monospot test results in rubella. Journal of the American Medical Association. 222, 585.

Rawsthorne, G.B., Cole, T.P. \& Kyle, J. (1970) Spontaneous rupture of the spleen in infectious mononucleosis. British Journal of Surgery, 57, 396.

REgistrar General (1974) Statistical review of England and Wales for 1972. Medical. Part I, London, H.M. Stationery Office.

Reisman, D.D. \& Logan, D.J. (1968) Rupture of the spleen secondary to renal sepsis. Journal of Urology, 98, 426.
Sadoff, L. \& Goldsmith, O. (1971) False positive infectious mononucleosis spot test in pancreatic carcinoma. Journal of the American Medical Association, 218, 1297.

Sakulsky, S.B., Wallace, R.B., Silverstein, M.N. \& DOCKERTY, M.B. (1967) Ruptured spleen in infectious mononucleosis. Archives of Surgery, Chicago, 94, 349.

Seltzer, M.H. \& Quarantillo, E.P. (1973) Spontaneous splenic rupture in an anticoagulated patient. Journal of the Medical Society of New Jersey, 70, 397.

ShapIRo, C.M. \& Horwitz, H. (1959) Infectious mononucleosis in the aged. Annals of Internal Medicine, 51, 1092.

Soyer, M.T., Merk, M.E. \& Aldrete, J.S. (1976) Spontaneous rupture of the spleen, an unusual complication of anticoagulant therapy. Archives of Surgery. Chicago, 111, 610.

Yurko, A.A., Winegarner, F.G. \& Kinsey, D.L. (1965) The danger of the ruptured spleen in infectious mononucleosis. Ohio State Medical Journal, 61, 995.

\title{
Chronic active hepatitis, haemolytic anaemia and Listeria monocytogenes bacteraemia
}

\author{
R. G. CHADWICK \\ B.M., M.R.C.P.
}

J. M. Graham

M.B., Dip.Bact., F.R.C.Path.

\section{Southampton General Hospital, Southampton}

\begin{abstract}
Summary
The association of chronic active hepatitis with haemolytic anaemia is well known. Both conditions may respond to steroid therapy which, in common with other causes of suppressed T-lymphocyte function, predispose to many types of infection. A case is described in which transient Listeria monocytogenes bacteraemia occurred and the patient recovered without antimicrobial therapy.
\end{abstract}

\section{History}

A 53-year-old woman was admitted to hospital with 3 weeks' history of jaundice, dark urine and pale faeces. She had been breathless on exertion, and tired for 1 week.

On examination she was pale, but deeply jaundiced. A firm, smooth, non-tender liver was palpable $10 \mathrm{~cm}$ below the costal margin. There was no splenomegaly and no skin stigmata of chronic liver disease.

Correspondence: Department of Medicine, Royal Free Hospital, Pond Street, London, NW3 2QG.

\section{Investigations}

Haemoglobin $6.7 \mathrm{~g} / \mathrm{dl}$, PCV 0.20, MCHC $33 \mathrm{~g} / \mathrm{dl}$, ESR $150 \mathrm{~mm}$ in the first hour; reticulocytes $16 \%$; direct Coombs' test negative; haptoglobin absent' Schumm's test weakly positive; sucrose water test negative; red cell life by ${ }^{51} \mathrm{Cr}$ labelling 15 days; stool blood loss normal; total bilirubin $200 \mu \mathrm{mol} / \mathrm{l}$ $(11.7 \mathrm{mg} / \mathrm{dl})$; direct van den Bergh $149 \mu \mathrm{mol} / \mathrm{l}$ $(8.7 \mathrm{mg} / \mathrm{dl})$; aspartate transaminase $357 \mathrm{u} . / 1$ (normal value 5-42 u./l); alkaline phosphatase KAu./dl; albumin $28 \mathrm{~g} / \mathrm{l}(2.8 \mathrm{~g} / \mathrm{dl})$; globulin $55 \mathrm{~g} / 1(5.5 \mathrm{~g} / \mathrm{dl})$; $\operatorname{IgC~} 35 \mathrm{~g} / 1(3.5 \mathrm{~g} / \mathrm{dl})$; serum caeruloplasmin 6.8 $\mathrm{mmol} / \mathrm{l}(43 \mathrm{mg} / \mathrm{dl})$; antinuclear factor 1 : 20 (speckled); smooth muscle antibody titre strongly positive; mitochondrial antibody absent; liver biopsy showed chronic aggressive hepatitis.

\section{Management}

The patient was treated with prednisolone $30 \mathrm{mg}$ reducing to $20 \mathrm{mg}$ daily. The haemolytic anaemia responded completely and the serum proteins and liver function tests returned to normal. 
Seventeen months later the prednisolone was stopped. After a further 8 weeks she was re-admitted with a 10-day history of worsening obstructive jaundice, anorexia and night sweats.

On examination she had deep jaundice and hepatomegaly as before, and was also febrile (temp. $38 \cdot 5 \mathrm{C})$.

\section{Further investigations}

Haemoglobin $9.9 \mathrm{~g} / \mathrm{dl}$; reticulocytes $3.3 \%$; direct Coombs' test weakly positive; weak titre of non-specific cold agglutinin; haptoglobin absent, Schumm's test negative; bilirubin $239 \mu \mathrm{mol} / 1$ $(14 \mathrm{mg} / \mathrm{dl})$; aspartate transaminase $>306 \mathrm{u} . / \mathrm{l}$; alkaline phosphatase $21 \mathrm{KAu} / \mathrm{dl}$; albumin $25 \mathrm{~g} / \mathrm{l}$ $(2.5 \mathrm{~g} / \mathrm{dl})$; globulin greater than $75 / \mathrm{gl}(7.5 \mathrm{~g} / \mathrm{dl})$.

A further liver biopsy 40 days after admission showed established cirrhosis. Haematological indices, serum, proteins, bilirubin, aspartate transaminase and alkaline phosphatase were seen to be normal on the sixtieth day.

\section{Progress}

The low grade pyrexia persisted until prednisolone therapy was started on the fourth day with doses up to $60 \mathrm{mg}$ daily. On the tenth and eleventh day, malaise and headaches were associated with a recurrence of pyrexia of $38.8^{\circ} \mathrm{C}$. Blood cultures produced a growth of Listeria monocytogenes type $1 / 2$ sensitive to ampicillin, erythromycin and streptomycin, resistant to penicillin. By the time the organism has been isolated the fever had settled without antibiotics, and repeat blood cultures were negative.

\section{Discussion}

The association of chronic active hepatitis and haemolytic anaemia is well recognized (Dacie, 1967).

$L$. monocytogenes is found widespread in nature with isolations described worldwide. Asymptomatic carriers are to be found particularly among workers in silage and meat production industries. The organism is found in the faeces and, less commonly, the nose and throat. There is no definite evidence of zoonotic transmission and $L$. monocytogenes is able to survive and multiply in soil (Seeliger, 1972).

$L$. monocytogenes has been described as the causative organism in genital infection, recurrent abortion, gastroenteritis and particularly meningoencephalitis. It is mainly a pathogen of neonates and the elderly, and an opportunist pathogen in those debilitated by malignant disease or cirrhosis (Ales Reinlein, Florez Alia and Soriano Garcia, 1974).

The propensity of patients with liver disease to develop bacteraemia, especially with enteric organisms is well known (Martin et al., 1956; Conn, 1964).
The cirrhotic liver has a reduced ability to trap foreign antigens. This may be due to the shunting o $\mathbb{R}$ portal blood, or to Kupffer cell insufficiency(Thomas, McSween and White, 1973).

T-lymphocytes are involved in the resistance to $\sigma^{+}$ infection with L. monocytogenes and it is known that suppression of T-lymphocyte function by steroids $\frac{\bar{\sigma}}{5}$ azathioprine or antilymphocytic serum predisposes particularly to this infection (Gray and Killingero 1966). Renal allograft patients are especially at risk pontomedullary infections (Nirmul et al., $1971 \overrightarrow{0}$ Mahony et al., 1974) and bacterial endocarditis (Leonard, Raij and Shapiro, 1973) are serious్ manifestations.

Results of antibiotic therapy are variable. Amo picillin is often effective treatment for $L$. mono cytogenes infection (Nirmul et al., 1971; McNair White and Graham, 1968). Penicillin may be suitable alternative, and both act synergistically with gentamicin or streptomycin (Moellering et al.ज़ 1972). Patients with no other underlying disease have better prognoses than do those already de $=$ bilitated by other conditions (Ales Reinlein et al. 1974; Medoff, Kunz and Weinberg, 1971).

This patient would appear to be exceptional in having recovered spontaneously from $L$. monocytogenes bacteraemia.

\section{Acknowledgment}

We wish to thank Dr J. Bamforth for his permission publish this account of his patient; Dr J. E. Middleton Chemical Pathologist, for the biochemical data, and DE Agnes Macara of the Standards Laboratory, Central Publiळ Health Laboratory, Colindale, for typing the organism.

\section{References}

Ales Reinlein, J.M., Florez Alia, C. \& Soriano Garciā̧ F. (1974) Infección por Listeria monocytogenes. Revistā Clinica Española, Madrid, 133, 205.

ConN, H.O. (1964) Spontaneous peritonitis and bacteremia in Laennec's cirrhosis caused by enteric organisms $\frac{\sigma}{3}$ Annals of Inernal Medicine, 60, 568.

Dacie, J.V. (1967) The Haemolytic Anaemias, Part III, 2n\& edn, p. 288. Churchill Livingstone, London.

Gray, M.L. \& Killinger, A.H. (1966) Listeria monocytogenes and listeric infections. Bacteriological Review, 30, 309음

Leonard, A. RaiJ \& Shapiro, F.L. (1973) Bacterial endo $\rightarrow$ carditis in regularly dialyzed patients. Kidney Inter을 national, 4, 407.

Macnair, D.R., White, J.E. \& Graham, J.M. (1968 Ampicillin in the treatment of Listeria monocytogenes meningitis. Lancet, i, 16.

Mahony, J.F., Tambyah, J.A., Dalton, V.C. \& Wolfenden Nu W.H. (1974) Pontomedullary listeriosis in renal allograf b recipient. British Medical Journal, 2, 705.

Martin, W.J., Spittel, J.A., Morlock, C.G. \& Baggene stoss, A.H. (1956) Severe liver disease complicated bxD bacteremia due to Gram-negative bacilli. Archives of Internal Medicine, 98, 8.

Medoff, G., Kunz, L.J. \& Weinberg, A.N. (1971) Listeriosis in humans; an evaluation. Journal of Infectious Diseases 123, 247. 
Moellering, R.C., Medoef, G., Leech, I., Wennersten, C. \& KUNZ, L.J. (1972) Antibiotic synergism against Listeria monocytogenes. Antimicrobial Agents and Chemotherapy, 1, 30.

Nirmul, G., Glabman, S., Haemov, M., Leiter, E. \& BurRows, L. (1971) Listeria monocytogenes meningitis during immunosuppression. New England Journal of Medicine, 285, 1323.
Seeliger, H.P.R. (1972) Proceedings: New outlook on the epidemiology and epizoology of listeriosis. Acta microbiologica academiae scientiarum hungaricae. Budapest, 19, 273.

Thomas, H.C., McSween, R.N.M. \& White, R.G. (1973) Role of the liver in controlling immunogenicity of commensal bacteria in the gut. Lancet, i, 1288. 